\title{
Comparison of techniques for ammonia emission mitigation during storage of livestock manure and assessment of their effect in the management chain
}

\author{
Alberto Finzi, ${ }^{1}$ Elisabetta Riva, ${ }^{1}$ Alda Bicoku, ${ }^{2}$ Viviana Guido, ${ }^{1}$ Seit Shallari, ${ }^{2}$ Giorgio Provolo ${ }^{1}$ \\ ${ }^{1}$ Department of Agricultural and Environmental Sciences, University of Milano, Italy; ${ }^{2}$ Department of Agri-Environment \\ and Ecology, Faculty of Agriculture and Environment Agricultural University of Tirana, Albania
}

\begin{abstract}
The reduction of ammonia $\left(\mathrm{NH}_{3}\right)$ emissions associated with manure management requires identification and implementation of effective techniques. The objective of this study was to measure potential ammonia emissions from animal manure and evaluate emission reductions for five mitigation techniques (straw, sawdust, clay, oil and sulphuric acid). Although numerous studies have evaluated individual mitigation techniques, the variability of their effect with different types of slurries has not been fully investigated. Furthermore, the assessment of ammonia emissions from the subsequent land application of stored manure (or slurry) using different techniques would indicate the practical consequences of the entire slurry management chain. The effects of mitigation techniques were evaluated using a model to simulate field application of slurry. Three techniques were compared: broadcast spreading, band spreading and closed-slot injection. Simulations utilised data from experiments conducted at a controlled temperature on six slurries of three different types: pig, cattle and digestate. Ammonia emissions from the raw slurries (i.e., untreated
\end{abstract}

Correspondence: Alberto Finzi, Department of Agricultural and Environmental Sciences, University of Milano, via Celoria 2, 20133 Milano, Italy.

E-mail: alberto.finzi@unimi.it

Key words: Livestock slurry; digestate; ammonia emission; mitigation technique; field application.

Acknowledgements: this study was conducted under the projects Innovative Manure Management and Treatment Techniques to Reduce Nutrient Nonpoint Source Pollution of Waters in Intensive Livestock Areas (ReNuWal), supported by Fondazione Cariplo (Grant No. 20141279), and LIFE ES/ENV/00040 - ARIMEDA Ammonia Emission Reduction In MEDiterranean Agriculture with Innovative Slurry Fertigation Techniques, part-funded by the European Union.

Received for publication: 26 July 2018.

Accepted for publication: 10 December 2018.

CCopyright A. Finzi et al., 2019

Licensee PAGEPress, Italy

Journal of Agricultural Engineering 2019; L:881

doi:10.4081/jae.2019.881

This article is distributed under the terms of the Creative Commons Attribution Noncommercial License (by-nc 4.0) which permits any noncommercial use, distribution, and reproduction in any medium, provided the original author(s) and source are credited. slurry) were determined using the dynamic chamber technique and compared with those from the slurries treated using each of five mitigation techniques. A subsample of one $1 \mathrm{~L}$ of each slurry was transferred into $2 \mathrm{~L}$ plastic bottles. An airflow of $1 \mathrm{~L} \mathrm{~min}^{-1}$ across the headspace was established and then emissions were measured over a period of $24 \mathrm{~h}$. The air outlet was connected to two serial acids traps filled with $1 \%$ boric acid. The quantity of $\mathrm{NH}_{3}$ trapped was determined by titration. Acidification and oil addition were the most effective techniques, reducing ammonia emission from raw slurries by more than $95 \%$ and $80 \%$, respectively. The mitigation effects of straw and sawdust were higher for cattle slurry and digestate than for pig slurry, while clay had an opposite effect. The overall assessment of ammonia emissions from storage and subsequent field application showed that acidification followed by closed-slot injection emitted at most $12 \%$ of the emissions from the reference system, while emissions from acidification followed by band spreading were between $14 \%$ and $22 \%$ of those from the reference system. The latter appears to be both more effective than broadcast spreading and technically more easily operated than a closed-slot injector.

\section{Introduction}

European agriculture is responsible of $94 \%$ of ammonia $\left(\mathrm{NH}_{3}\right)$ emissions in Europe (European Environment Agency, 2017), and approximately $75 \%$ of $\mathrm{NH}_{3}$ emissions derive from livestock manure management (Webb et al., 2005). $\mathrm{NH}_{3}$ volatilisation during manure storage represents approximately $19 \%$ of nitrogen $(\mathrm{N})$ excreted by animals housed in barns, and an additional 19\% is lost during field application of the manure (Oenema et al., 2007).

The most important factors influencing $\mathrm{NH}_{3}$ emission from slurry are the concentration of total ammoniacal nitrogen (TAN) in the slurry, the emitting surface, $\mathrm{pH}$ of the slurry, the air velocity and the slurry temperature (Feilberg and Sommer, 2013). To reduce $\mathrm{NH}_{3}$ emissions during manure/slurry storage and subsequent land application, mitigation techniques must be implemented that are able to reduce the effects of these parameters. Strategies examined by the scientific community for reducing $\mathrm{NH}_{3}$ losses are numerous and the reported effectiveness of the strategies varies significantly (Ndegwa et al., 2008; Hou et al., 2015).

A possible solution for abating $\mathrm{NH}_{3}$ emissions from slurry is the use of additives during slurry storage, such as urease inhibitors, adsorbents, acidifying additives, saponins, and digestive-biological additives (McCrory and Hobbs, 2001). Urease inhibitors have shown promise at the laboratory scale, but their use has not become widespread in practice (Ndegwa et al., 2008). Digestive-biological additives have yielded contrasting results (Provolo et al., 2016) as have adsorbents such as peat, saponins 
and specific additives (Ndegwa et al., 2008). Zeolite and perlite as adsorbents have yielded less variable results (Hörnig et al., 1999; Portejoie et al., 2003). Acidification has a particular relevance as a mitigation technique in the whole-chain manure management system from housing to land application, given its high capacity to reduce not only $\mathrm{NH}_{3}$ emissions, but also emissions of other greenhouse gases (GHG) (Kai et al., 2008; Fangueiro et al., 2015; Hou et al., 2015; Misselbrook et al., 2016; Regueiro et al., 2016; Mohankumar Sajeev et al., 2018). Addition of sulphuric acid $\left(\mathrm{H}_{2} \mathrm{SO}_{4}\right)$, hydrochloric acid $(\mathrm{HCl})$ and nitric acid $\left(\mathrm{HNO}_{3}\right)$ to slurry can reduce $\mathrm{NH}_{3}$ emissions (McCrory and Hobbs, 2001). Strong acids such as these provide better results than weaker acids (such as lactic, acetic or citric acid) because of the former's greater capacity for $\mathrm{pH}$ reduction (Regueiro et al., 2016). As regards GHGs, methane $\left(\mathrm{CH}_{4}\right)$ emissions from slurry are significantly reduced by acidification (Petersen et al., 2012, 2014), while reduction of nitrous oxide $\left(\mathrm{N}_{2} \mathrm{O}\right)$ emissions from land-applied acidified slurry is variable (Petersen and Sommer, 2011; Mohankumar Sajeev et al., 2018).

Another approach for reducing $\mathrm{NH}_{3}$ emissions from manure/slurry is to cover the storage facility by using a tent roof or floating cover on the slurry surface (Guarino et al., 2006; Ndegwa et al., 2008), even if the effects of storage covers on GHG emissions are not well defined (VanderZaag et al., 2008). A cover can reduce $\mathrm{NH}_{3}$ emission by decreasing the airflow across the slurry surface, but can increase emissions of GHG, especially $\mathrm{N}_{2} \mathrm{O}$ (Hansen et al., 2009; Rodhe et al., 2015). Several typologies of covers have been investigated. Floating covers can be constructed of a variety of materials that provide very different performances, length of service and strength during homogenisation of the stored slurry (Guarino et al., 2006; Ndegwa et al., 2008).

The natural crust that forms on some slurries serves as a reliable and inexpensive cover, but the integrity of the crust is strictly dependent on the dry matter content of the slurry (Misselbrook et al., 2005). Studies using straw, sawdust and wood chips as supplemental crust materials have observed a reduction of $\mathrm{NH}_{3}$ emissions (Hörnig et al., 1999; Guarino et al., 2006). These materials tend to reduce or have no effect on $\mathrm{CH}_{4}$ emissions, and increase $\mathrm{N}_{2} \mathrm{O}$ emissions (Hansen et al., 2009). Leca ${ }^{\circledR}$ (or expanded clay), has a significant effect on $\mathrm{NH}_{3}$ emissions abatement (Balsari et al., 2006; Guarino et al., 2006; Misselbrook et al., 2016), as do perlite and zeolite (Hörnig et al., 1999; Portejoie et al., 2003). Oil (Portejoie et al., 2003; Guarino et al., 2006) and plastic-synthetic film (Hörnig et al., 1999; Portejoie et al., 2003) used alone or as supplemental materials have greater potential among all the covers discussed, even considering that over time oil tends to mix with the crust and lose effectiveness (Hörnig et al., 1999).

Regardless of the adopted strategy to reduce or eliminate $\mathrm{NH}_{3}$ emissions from storages, the techniques exert their main effect only during one stage of the manure management chain. The subsequent process of utilising the stored manure/slurry on land must be done carefully to avoid losing the $\mathrm{NH}_{3}$ emission reduction benefits gained during storage (Hou et al., 2015). Land application techniques such as injection of slurry into closed or open slots allow slurry to be incorporated beneath the soil. These and other techniques such as band spreading using a trailing hose or trailing shoe are preferable to broadcast spreading because they reduce the exposed slurry surface and favour infiltration (Santonja et al., 2017). The evaluation and comparison of land application techniques in terms of $\mathrm{NH}_{3}$ emissions can be accomplished using models specifically developed for this purpose. Several models have been developed (Søgaard et al., 2002; Thorman et al., 2008; Loubet et al., 2010; Langevin et al., 2015;
Hafner et al., 2018), but among them, ALFAM model (Søgaard et al., 2002) is the most used.

Although numerous studies have been conducted on techniques that mitigate $\mathrm{NH}_{3}$ emission, the variability in the effectiveness of these techniques for different types of slurries has not been fully investigated. Furthermore, assessments have rarely considered the effectiveness of a given emission reduction technique throughout the entire manure management chain. The assessment of $\mathrm{NH}_{3}$ emissions during storage and the subsequent land application process using different mitigation techniques would provide useful indications of the practical consequences of these techniques throughout the slurry management chain.

In this study, laboratory experiments were combined with mathematic simulation to compare five $\mathrm{NH}_{3}$ emission mitigation techniques applied to six types of slurries. The objective of the study was to analyse the effectiveness of each mitigation technique in reducing $\mathrm{NH}_{3}$ emissions, and to quantify the effectiveness as a function of the type and composition of slurry. Then, based on the experimental results, $\mathrm{NH}_{3}$ emissions during land application of the slurries were simulated, comparing three application techniques. The overall assessment of the slurry management chain (from storage to land application) identified the most effective combination of techniques for reducing $\mathrm{NH}_{3}$ emissions.

\section{Materials and methods}

\section{Slurries used in the experiments}

The effect of different $\mathrm{NH}_{3}$ emission mitigation techniques was evaluated on six types of slurries (two pig slurries; two cattle slurries and two digestate) collected from commercial farms in the Italian region of Lombardy.

Pig slurry no. 1 was collected from a fattening pig farm in Pompiano (BS) where animals were housed on a slatted floor with a slurry storage pit located underneath. The sample from this farm came from the liquid fraction resulting from separation of the raw slurry using screw press equipment.

Pig slurry no. 2 came from a fattening pig farm located in Camisano (CR) where animals were housed on a slatted floor with a shallow slurry receiving pit underneath that was emptied periodically with a vacuum system. The sample was taken from the receiving pit without further treatment.

Cattle slurry no. 1 was collected from a dairy cow farm in Lodi Vecchio (LO) where animals were housed in cubicles. The sample was obtained from a storage tank that received slurry from different buildings.

Cattle slurry no. 2 was obtained from a dairy cow farm in Caravaggio (BG) and was collected from a pit that received manure scraped from the solid floor of the passageways in buildings where the animals were housed.

Digestate no. 1 was obtained from a cooperative biogas plant ( $1 \mathrm{MWe}$ ) in Martinengo (BG). The feedstock was comprised of $35 \%$ pig slurry, $50 \%$ cattle slurry, $5 \%$ poultry and cattle manure, and $10 \%$ other biomass (maize and sorghum silage, corn flour). Samples were obtained from the liquid fraction of the digestate following mechanical separation (screw press).

Digestate no. 2 was obtained from a farm biogas installation $(250 \mathrm{kWe})$ in Lodi Vecchio (LO). The feedstock was comprised of $90 \%$ cattle slurry and $10 \%$ corn silage. Samples were taken from raw digested slurry (digestate).

Each slurry was analysed before an experiment to determine 
the content of total Kjeldahl nitrogen (TKN), TAN, total solids (TS), volatile solids (VS), and $\mathrm{pH}$ using standard methods (APHA/AWWA/WEF, 2012).

\section{Experimental conditions}

Ammonia emissions from the various slurries and treatments were determined using the dynamic chamber method according to the methodology used for laboratory scale studies by other researchers (Dinuccio et al., 2008; Petersen et al., 2012).

A subsample of one $1 \mathrm{~L}$ of each slurry was transferred into 2 L plastic bottles (Petersen et al., 2012). An airflow of $1 \mathrm{~L} \mathrm{~min}^{-1}$ across the headspace was established and then emissions were measured over a period of $24 \mathrm{~h}$. The air outlet was connected to two serial acids traps filled with $1 \%$ boric acid. The bottles were placed in a controlled temperature container set at $20^{\circ} \mathrm{C}$ to avoid effect of temperature variation during an experiment. The lids of the bottles were connected to two Teflon ${ }^{\circledR}$ tubes $(6 \mathrm{~mm}$ inner diameter). One tube (the air inlet) was open to draw in ambient air. The second tube (the air outlet) was connected to the first of two Drechsel bottles containing $200 \mathrm{~mL}$ of $1 \%$ boric acid solution to capture the $\mathrm{NH}_{3}$ contained in the air discharged from the sample bottle. The second Drechsel bottle was connected to a gas measuring indicator and an analog flow meter to regulate and monitor the flow of air obtained from the chamber system. The air was drawn through the piping system at a continuous flow rate of $1 \mathrm{~L} \mathrm{~min}^{-1}$ by a pump (EVO30 series, Ead) connected to the analogue flow regulator. An additional acid trap was used as reference to measure the $\mathrm{NH}_{3}$ concentration of the ambient air. Before each experiment, the flows were calibrated using a digital flow meter (PFM710S-C4-A, SMC). At the end of each experiment, the contents of the Drechsel bottles were titrated with $0.1 \mathrm{~N}$ sulphuric acid to determine the amount of $\mathrm{NH}_{3}$ trapped.

The $\mathrm{NH}_{3}$ emissions were calculated according to Eq. (1):

$$
E=\frac{\left(M_{\text {out }}-M_{\text {in }}\right)}{T \cdot V}
$$

where $E$ is the emission ( $\mathrm{mg}$ day $\left.{ }^{-1} \mathrm{~L}^{-1}\right), M_{\text {out }}$ is the mass (mg) of $\mathrm{NH}_{3}$ captured in the Drechsel bottles (acid traps), $M_{\text {in }}$ is the mass (mg) of $\mathrm{NH}_{3}$ in the reference acid trap, and $T$ is the duration of the sampling period (day) and $V$ the volume of the slurry in the bottle (L). To compare the results with other previously reported research, the emissions were referenced also to the initial TAN and TKN content.

Ammonia emissions from each treatment-slurry combination were measured for $24 \mathrm{~h}$ in duplicate using raw (untreated) slurry as reference and the following mitigation techniques:

- Straw: a layer approximately $1 \mathrm{~cm}$ thick of barley straw was carefully placed on the surface of slurry in both bottles;

- Sawdust: a sawdust layer approximately $1 \mathrm{~cm}$ thick was placed on the surface of slurry in both bottles;

- Clay: an amount of commercial clay granules was scattered on the slurry surface to achieve complete coverage in both bottles;

- Oil: oil was gently poured onto the slurry surface to create a layer $3 \mathrm{~mm}$ thick in both bottles;

- Acidification: sulphuric acid (98\% purity) was added to the slurry in both bottles and gently mixed; acid was added until the $\mathrm{pH}$ of the mixture was less than 5.5.
Each technique was applied soon after filling the bottles with raw slurry and just before the start of the experiments.

\section{Statistical analysis}

To evaluate the effect of the mitigation techniques on each slurry, the Kruskal-Wallis test was performed using the software R (version 3.5.0, https://www.r-project.org/). The alpha parameter was set as 0.05 , and the Fisher's least significant difference was used as the criterion for the post-hoc test.

\section{Assessment of the slurry management chain}

To assess the effect of each mitigation technique used during slurry storage on the entire management chain, the distribution techniques for applying the slurry to land had to be considered. To do so, the $\mathrm{NH}_{3}$ emissions from slurry during field application with different approaches (broadcast spreading, band spreading and closed-slot injection) were simulated. The procedure to realise the simulation involved the following steps:

- Selection of Ef for raw slurry (i.e., untreated slurry) during the entire storage period. The values selected referred to slurry storage in open tanks, i.e., $9 \%$ for cattle slurry, $15 \%$ for pig slurry and $28 \%$ for digestate (Feilberg and Sommer, 2013).

- Calculation of emission reductions resulting from different coverings and acid addition when compared to emissions from raw slurry, using the results of the experiments.

- Estimation of $E f$ for the land application of slurry. This emission factor referred to the initial content of TAN applied on the field and was estimated for the three techniques evaluated using the ALFAM model (Søgaard et al., 2002). To calculate $\mathrm{NH}_{3}$ losses during field application, the values for parameters in the model were set as follows. For TS and TAN, the values of chemical analyses made in the experimental part of this study were used. Soil moisture was set to wet, air temperature was set at $18^{\circ} \mathrm{C}$ (average temperature during the land application period), and wind speed was set at $2 \mathrm{~m} \mathrm{~s}^{-1}$. The slurry type was set to pig or cattle according to the type, and digestate was considered as cattle slurry. The application rate, expressed in metric tons per ha $\left(\mathrm{t} \mathrm{ha}^{-1}\right)$, was calculated for each slurry type on the basis of its TKN content and assuming an application of $340 \mathrm{~kg} \mathrm{TKN} \mathrm{ha}{ }^{-1}$. The model was used considering that the slurry is not incorporated and setting the wind tunnel as measuring technique.

- For acidified slurries, not included as option in the ALFAM model, an average reduction in $\mathrm{NH}_{3}$ losses was considered. A $60 \%$ reduction of losses compared to raw slurry was assumed (Kai et al., 2008; Fangueiro et al., 2015).

- Storage of raw slurries without mitigation techniques followed by field application using a broadcast spreader was considered as the reference management chain for each slurry. Total $\mathrm{NH}_{3}$ losses for the reference management chain were obtained by adding the emissions during storage to the emissions from broadcast spreading, calculated relative to the residual TAN after storage.

- The total $\mathrm{NH}_{3}$ emissions from each management chain were compared to those from the reference chain and the proportions of $\mathrm{NH}_{3}$ emissions attributable to storage and field application were calculated. 


\section{Results and discussion}

\section{Comparison of mitigation techniques}

The initial characteristics of the slurries as collected are reported in Table 1.

The results shown in Table 2 highlight a statistically significant difference $(\mathrm{P}<0.05)$ for all the mitigation techniques for each of the six slurries examined, with the exception of slurry Cattle no. 1 for which the effects were less obvious. The interactions raw-straw, straw-sawdust, clay-oil, sawdust- $\mathrm{H}_{2} \mathrm{SO}_{4}$ were not statistically significant. For Cattle no. 1 the $\mathrm{NH}_{3}$ emissions were affected by the high TS content $(8.7 \%)$ that might have masked the effect of the mitigation techniques more strongly than for the other slurries. Although high TS content reduces $\mathrm{NH}_{3}$ emissions and makes formation of a natural crust easier (Misselbrook et al., 2005), there was not enough time for crust formation in this study. Nevertheless, the effects of floating covers on $\mathrm{NH}_{3}$ emission were more pronounced for slurries with relatively low TS content and the differences were diminished for slurries with high TS content, especially with sawdust for which the performance was comparable to that of acid. Cattle no. 1 and Cattle no. 2 emitted less $\mathrm{NH}_{3}$ than Pig and Digestate samples because of the higher TS content of the cattle slurries, lower TAN and acidic $\mathrm{pH}$ (but near neutral). On the contrary Digestate no. 1 and Digestate no. 2 had higher $\mathrm{NH}_{3}$ emissions than the other slurries (except Pig no. 2) because of their higher TAN content and alkaline $\mathrm{pH}$, which was similar to that for Pig no. 1 and Pig no. 2. As reported in Table 3 and Figure 1 , for almost all slurries $\mathrm{H}_{2} \mathrm{SO}_{4}$ addition resulted in largest reduction of $\mathrm{NH}_{3}$ emissions ( $>89 \%$, mean $95 \%$ ), followed by oil $(>75 \%$ emission reduction, mean $87 \%$ ). The single exception to these results was for sample Cattle no. 1 because the effect of sawdust ( $95 \%$ emission reduction) was stronger on Cattle no. 1 than on other slurries, probably due to the sawdust's combination with the fibres already present in the slurry. These reductions are in agreement with those reported in other studies, and slightly better in

Table 1. Chemical characteristics of the slurries used in the experiments.

\begin{tabular}{|c|c|c|c|c|c|c|}
\hline Slurry & $\mathrm{pH}$ & TKN $\left(\mathrm{g} \mathrm{L}^{-1}\right)$ & TAN $\left(\mathrm{g} \mathrm{L}^{-1}\right)$ & TAN/TKN & TS (\%) & VS/TS (\%) \\
\hline Pig no. 1 & 7.9 & 2.95 & 2.55 & 86 & 1.3 & 46 \\
\hline Pig no. 2 & 7.7 & 5.13 & 3.60 & 70 & 5.0 & 59 \\
\hline Cattle no. 1 & 6.7 & 3.34 & 1.64 & 49 & 8.7 & 82 \\
\hline Cattle no. 2 & 7.2 & 2.43 & 0.99 & 41 & 7.0 & 84 \\
\hline Digestate no. 1 & 8.2 & 6.01 & 4.13 & 69 & 3.6 & 63 \\
\hline Digestate no. 2 & 8.0 & 4.11 & 2.44 & 59 & 6.9 & 74 \\
\hline
\end{tabular}

TKN, total Kjeldahl nitrogen; TAN, total ammoniacal nitrogen; TS, total solids; VS, volatile solids.

Table 2. Ammonia losses (as total ammoniacal nitrogen) of six slurries (mean and standard deviation). Post-hoc test $(\mathbf{P}<0.05)$ on mitigation techniques are related to each slurry sample.

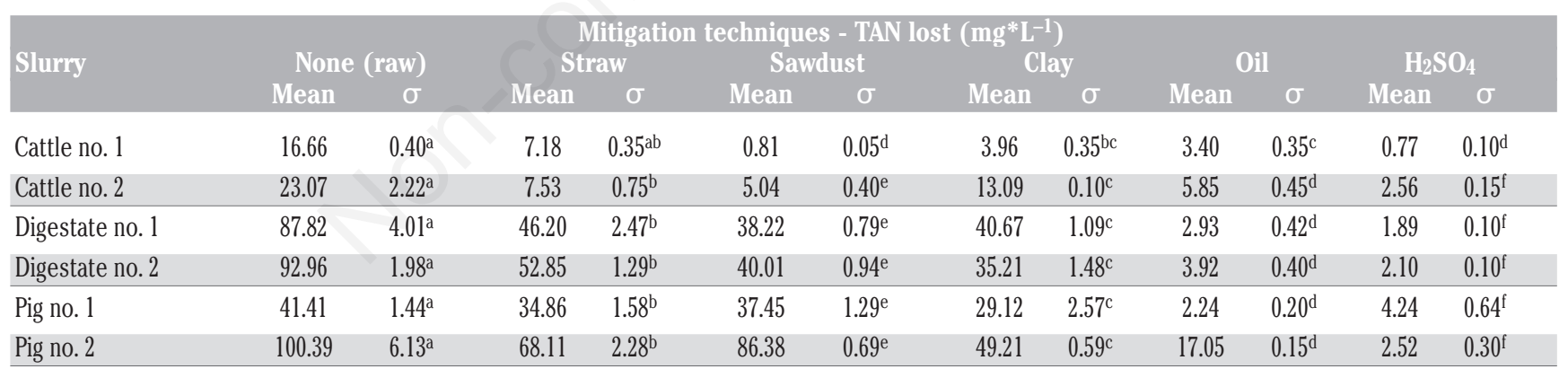

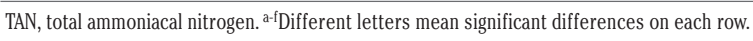

Table 3. Reductions of total ammoniacal nitrogen losses using various mitigation techniques compared to losses from raw (untreated) slurries.

\begin{tabular}{|c|c|c|c|c|c|c|c|}
\hline Mitigation techniques & Mean & Cattle no. 1 & $\begin{array}{r}\text { Cattle no. } 2 \\
\text { Reduct }\end{array}$ & $\begin{array}{c}\text { Slurries } \\
\text { Digestate no. } 1 \\
\text { of TAN losses }\end{array}$ & $\begin{array}{l}\text { Digestate no. } 2 \\
\text { f raw losses) }\end{array}$ & Pig no. 1 & Pig no. 2 \\
\hline Straw & 44 & 57 & 67 & 47 & 43 & 16 & 32 \\
\hline Sawdust & 52 & 95 & 78 & 56 & 57 & 10 & 14 \\
\hline Clay & 53 & 76 & 43 & 54 & 62 & 30 & 51 \\
\hline Oil & 87 & 80 & 75 & 97 & 96 & 95 & 83 \\
\hline $\mathrm{H}_{2} \mathrm{SO}_{4}$ & 95 & 95 & 89 & 98 & 98 & 90 & 97 \\
\hline
\end{tabular}

TAN, total ammoniacal nitrogen. 
some cases. As regards acidification, Regueiro et al. (2016) acidified cattle and pig slurry to $\mathrm{pH} 5.5$ using sulphuric acid and aluminium sulphate. The $\mathrm{H}_{2} \mathrm{SO}_{4}$ reduced emissions from pig slurry by $75 \%$ and emissions from dairy cow slurry by $81 \%$; likewise, the aluminium sulphate reduced emissions by $69 \%$ from pig slurry and by $87 \%$ from dairy slurry. Misselbrook et al. (2016) added sulphuric acid to cattle slurry and achieved a $75 \%$ reduction of $\mathrm{NH}_{3}$ emissions during two months of storage. Petersen et al. (2014) reported an emission reduction of $84 \%$ from pig slurry acidified to $\mathrm{pH} 5.5$ and a reduction of $49 \%$ from pig slurry acidified to $\mathrm{pH} 6.5$. The emission reduction from pig slurry $(<93 \%)$ achieved using oil in this study is aligned with results of Portejoie et al. (2003). Guarino et al. (2006) covered slurry with $3 \mathrm{~mm}$ of oil and achieved emission reductions of $79.5 \%$ for pig slurry and $68.5 \%$ for cattle slurry. In contrast, Hornig et al. (1999) achieved only a 50\% reduction of emissions from pig slurry covered with $3 \mathrm{~mm}$ of oil. Straw almost halved (mean 44\%) $\mathrm{NH}_{3}$ emission compared to emissions from raw slurry, while sawdust (mean 52\%) and clay (mean 53\%) provided slightly better abatements. For Pig no. 1 and Pig no. 2, the effects of the straw and sawdust were lower (10-32\%) compared to the effect on Cattle slurries (57-95\%) and Digestates (43-56\%); nevertheless, the effects were statistically significant (Table 2). These coverings (straw and sawdust) exhibited poor performance on the pig slurries probably due to the low level of TS and the low ratio VS/TS of these slurries; both parameters promoted precipitation of solids rather than crust formation. This lower capacity to reduce emissions was also reported by Guarino et al. (2006), even though their research showed slightly better performance on pig slurry (34.2\%) and cattle slurry (58.6\%), as did the study of Hörnig et al. (1999) on pig slurry (30\%). The cover with straw reduces $\mathrm{NH}_{3}$ emissions but might increase $\mathrm{N}_{2} \mathrm{O}$ emission, with a greater impact if it is kept dry rather than wet (Hansen et al., 2009).
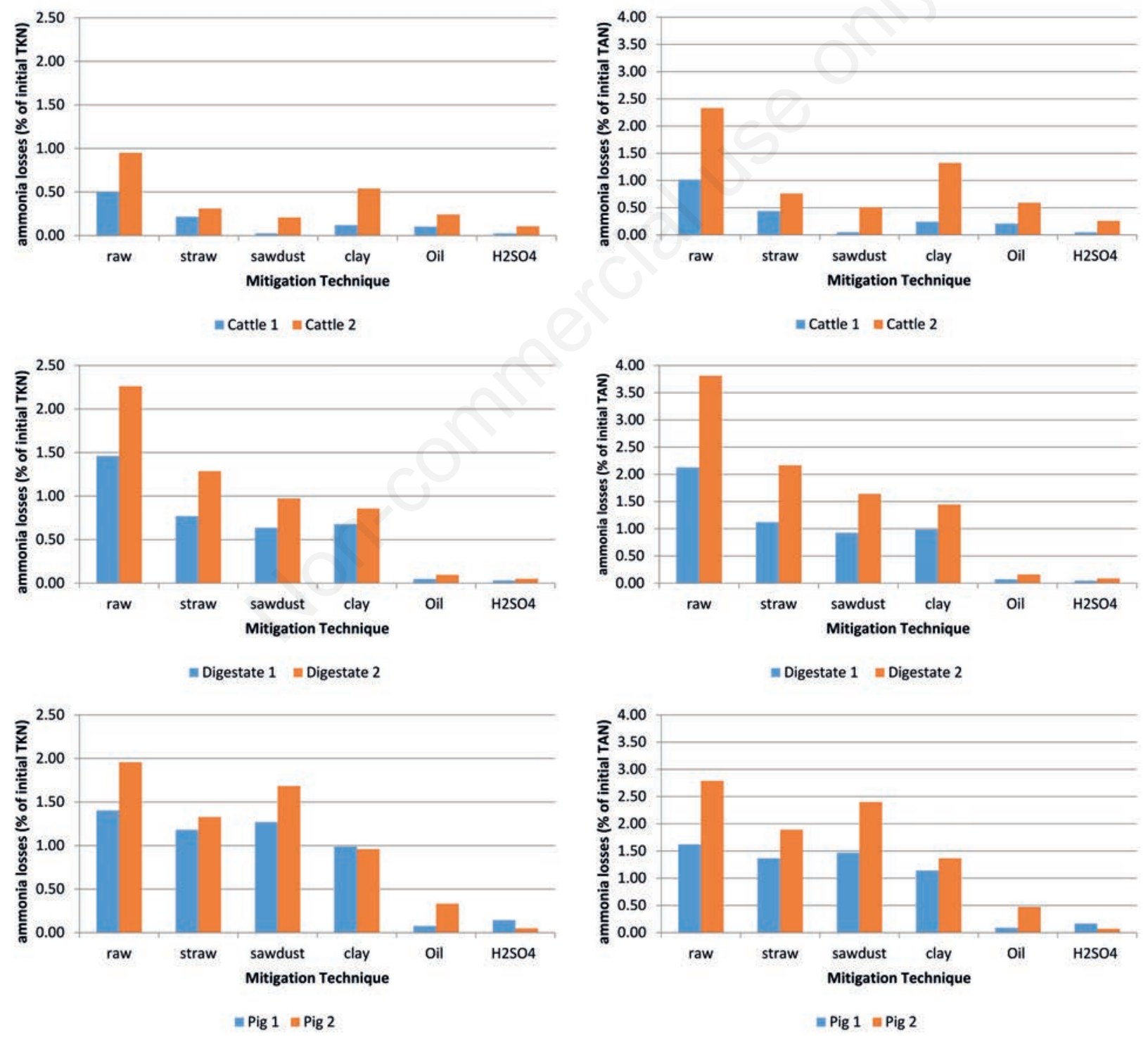

Figure 1. Losses of ammonia compared to the initial total Kjeldahl nitrogen (TKN) and total ammoniacal nitrogen (TAN) content, after 1 day. 
The emission reduction effectiveness of clay was greater for Cattle no. $1(76 \%)$ than for Cattle no. $2(43 \%)$ and for other samples (30-62\%) (Figure 1). The average $\mathrm{NH}_{3}$ emission reduction achieved using clay was $53 \%$ considering all slurries. Contrasting results from the use of clay have been reported by others. Balsari et al. (2006) achieved $\mathrm{NH}_{3}$ emission reductions from pig slurry of $73 \%$ and $87 \%$, in winter and summer respectively, and Misselbrook et al. (2016) achieved an emission reduction of $77 \%$ on pig slurry. Guarino et al. (2006) reported a very low emission reduction effect of clay both on pig slurry $(16.8 \%)$ and cattle slurry $(1.9 \%)$.

\section{Assessment of the slurry management chain from stor- age to field application}

As described in the previous section, floating covers and acidification facilitated a significant reduction of $\mathrm{NH}_{3}$ losses from stored slurries. However, high residual TAN in slurry after storage could result in higher emissions during land application, especially if a broadcast spreader was used (Figure 2). This observation was true for all mitigation techniques except acidification, which achieved better reductions of $\mathrm{NH}_{3}$ emissions during both storage and the subsequent land application of the stored slurries.

Considering the reference system (raw slurry and broadcast spreading), the cumulative $\mathrm{NH}_{3}$ losses referenced to the initial TAN content were: $57.3 \%$ for Cattle no. $1,46.4 \%$ for Cattle no. 2 , $47 \%$ for Digestate no. $1,59.4 \%$ for Digestate no. $2,28.5 \%$ for Pig no. 1 , and $35.4 \%$ for Pig no. 2. Pig slurries have lower emissions during land application than Cattle slurry and Digestate due to the lower TS content of Pig slurry and consequently quicker infiltration into the soil, reducing the exposure time of the liquid on soil surface (Søgaard et al., 2002). As regards the effect of broadcast spreading on application emissions after storage with different mitigation techniques (Figure 2A), for Cattle slurry there was a reduction of $56.8 \%$ (acid) and an increase of $8.7 \%$ (sawdust) compared to the effect on raw slurry. For Digestate, there was a reduction of $45.3 \%$ (acid) and an increase of $40 \%$ (oil). Likewise, for Pig slurry there was a reduction of $53.4 \%$ (acid) and an increase of $20.7 \%$ (oil). The mitigation techniques that achieved the greatest reduction of $\mathrm{NH}_{3}$ emission besides acidification (i.e., sawdust for Cattle samples and oil for Digestate and Pig samples) lost most of their effectiveness due to emissions at field application. However, even though $\mathrm{NH}_{3}$ emissions during application with a broadcast spreader increased for slurries after covered storage, the overall emissions were lower than those from raw slurry (although the benefit is very small for some techniques). As regards Cattle slurry, overall emissions represented between $91 \%$ (sawdust) and 96\% (straw) of all losses in the management chain when the slurries were land applied with a broadcast spreader. For Digestate the comparable values were between 58\% (oil) and $89 \%$ (straw), and for Pig slurry they were between $58 \%$ (oil) and $96 \%$ (sawdust). On the contrary the effect of acidification on the manure management chain was always relevant (38\% overall emission for Cattle slurry; $27 \%$ for Pig slurry and $23 \%$ for Digestate). These results are in line with those reported by Hou et al. (2015), which in comparison to reference conditions (no storage mitigation and broadcast spreading) showed an overall reduction of $\mathrm{NH}_{3}$ emissions by floating covers during storage despite an increase in emissions from the subsequent land application. Nevertheless, acidification was the most effective mitigation technique, especially if combined with soil incorporation of slurry following storage. The two techniques for field application, band spreading (Figure 2B) and closed-slot injection (Figure 2C) compared to the reference technique of broadcast spreading, did not affect the performance ratio among mitigation techniques during storage, but reduced $\mathrm{NH}_{3}$ field emissions. According to Søgaard et al. (2002), these techniques respectively emit just $58 \%$ and $27 \%$ of the $\mathrm{NH}_{3}$ emitted by the broadcast spreader. Considering the entire slurry management chain, emissions by the band spreader (Figure 2B) were lower than those from the reference system by approximately $35 \%$ (raw) and $88 \%$ (sulphuric acid) for Cattle slurry, by $22 \%$ (raw) and $86 \%$ (sulphuric acid) for Digestate, and by $25 \%$ (raw) and $83 \%$ (sulphuric acid) for Pig slurry. The emission reduction performance of acidification coupled with band spreading was similar to that found by Kai et al. (2008) who reported an emission rate of $71 \%$ less than a reference system considering storage and field application.

Overall $\mathrm{NH}_{3}$ emissions of closed-slot injection (Figure 2C) were lower than those from the reference system by approximately $61 \%$ (raw) and 89\% (sulphuric acid) for Cattle slurry, 39\% (raw) and $93 \%$ (sulphuric acid) for Digestate, and $42 \%$ (raw) and $92 \%$ (sulphuric acid) for Pig slurry.

\section{Conclusions}

All mitigation techniques assessed in this study can achieve a significant reduction in $\mathrm{NH}_{3}$ emissions from slurry storage for the three types of slurry examined; however, the type of slurry and its chemical composition affect the mitigation effect. Pig slurry and Digestate tend to have higher $\mathrm{NH}_{3}$ emission potential than Cattle slurry. Among the techniques evaluated, acidification provides the best abatement of $\mathrm{NH}_{3}$ emission during slurry storage with an average reduction of $95 \%$, followed by covering slurry with oil (87\%). Other floating covers using solid materials (straw, sawdust and clay) are less effective $\left(\mathrm{NH}_{3}\right.$ emissions reductions of $44 \%$ $53 \%$ ) than acidification and oil, except in the case of sawdust used to cover Cattle slurry.

$\mathrm{NH}_{3}$ emission factors for storage cannot be considered independently from the slurry characteristics, even for slurries of the same type. Reductions of $\mathrm{NH}_{3}$ emissions may vary by $30 \%$ for the same type of slurry and mitigation technique, and by more than $50 \%$ among slurries. Therefore, to accurately assess $\mathrm{NH}_{3}$ emissions from slurry, specific EFs have to be used. Further studies are required to improve knowledge of factors that influence $\mathrm{NH}_{3}$ emissions in practical conditions when the use rigid or flexible covers are not feasible. Considering the entire slurry management chain, acidification seems to be the most effective $\mathrm{NH}_{3}$ emission reduction technique as its effect continues during field application following storage. Unfortunately, the $\mathrm{pH}$ of acidified slurry may rise during storage and necessitate further addition of acid. Other mitigation techniques that are more limited than acidification in reducing $\mathrm{NH}_{3}$ emissions during storage tend to lose overall effectiveness if the stored slurry is subsequently land-applied using a broadcast spreader. Therefore, for effective overall reduction of $\mathrm{NH}_{3}$ emissions, such mitigation techniques during storage should be combined with a technique that controls emissions during land application, such as band spreading or closed-slot injection. Considering the cumulative $\mathrm{NH}_{3}$ emissions throughout the slurry management chain from storage to subsequent field application, acidification combined with closed-slot injection can achieve remarkable emission reductions (emissions at least $88 \%$ lower than those from a reference system). Acidification followed by band spreading also can achieve good emission control, producing $\mathrm{NH}_{3}$ emissions that are $78-86 \%$ lower than those from a reference system. The latter appears to be both more effective than broadcast spreading and technically more easily operated than closed-slot injection. 
Broadcast spreader

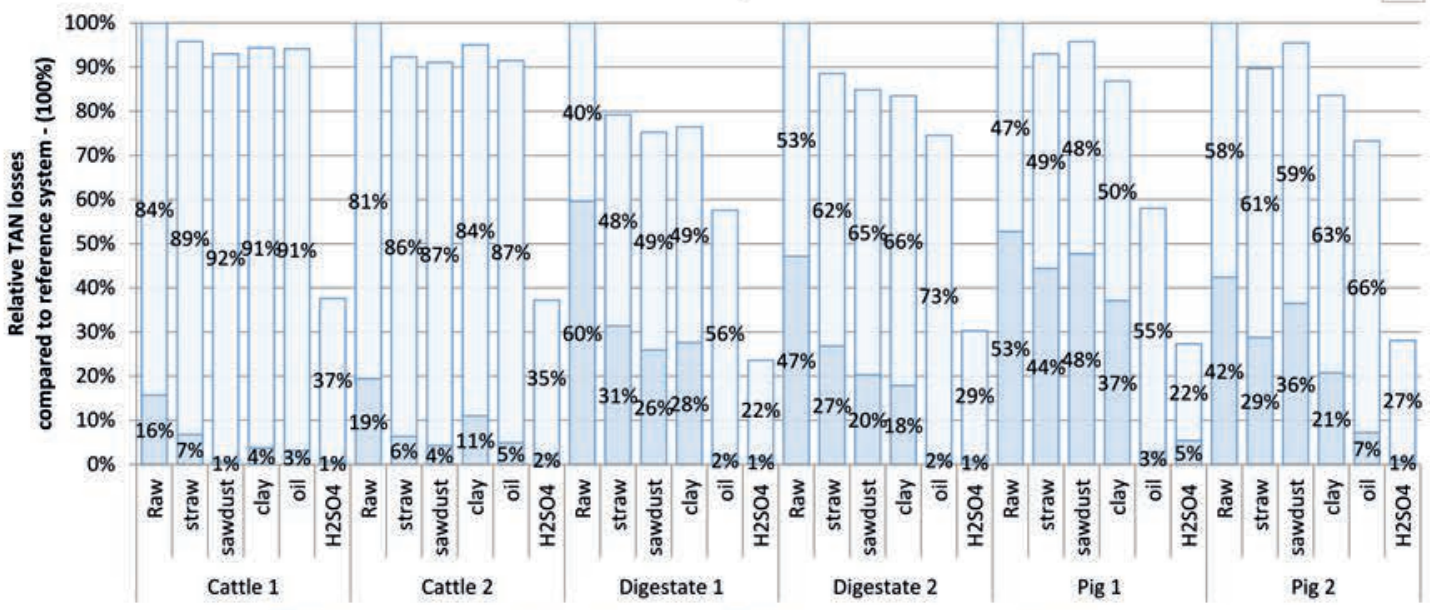

$\square$ TAN losses from storage (\% Total losses) $\quad \square$ TAN losses from application (\% Total losses)

\section{Band spreader}

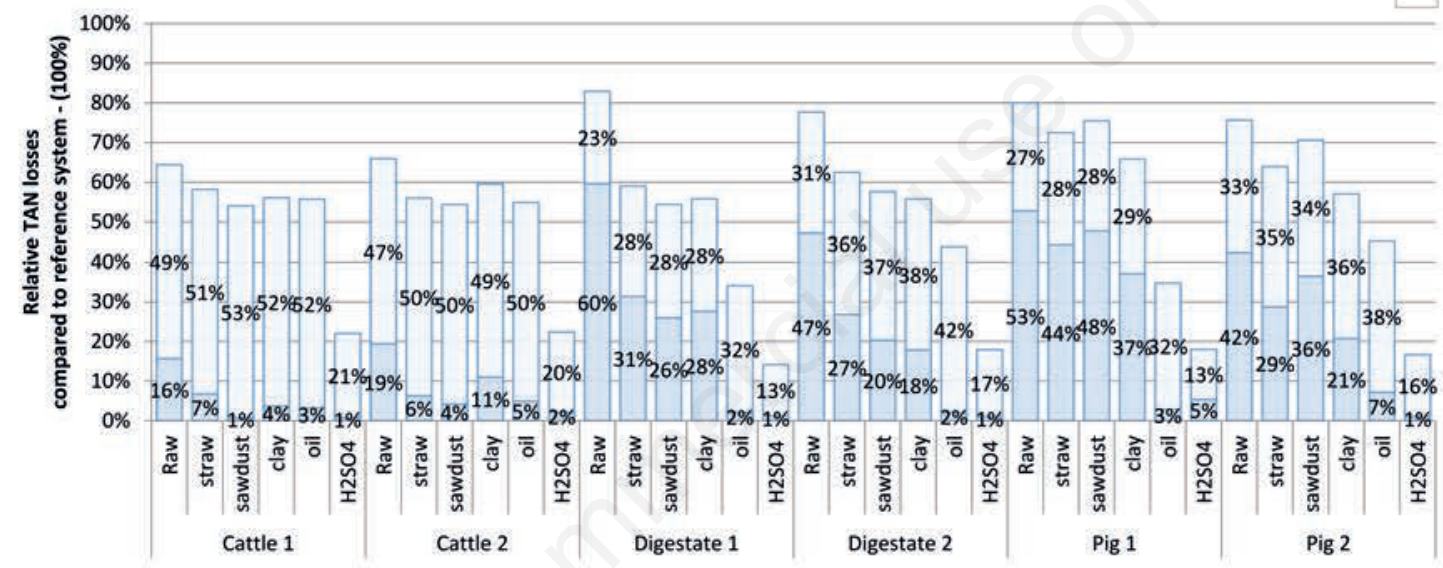

$\square$ TAN losses from storage (\% Total losses) $\quad \square$ TAN losses from application (\% Total losses)

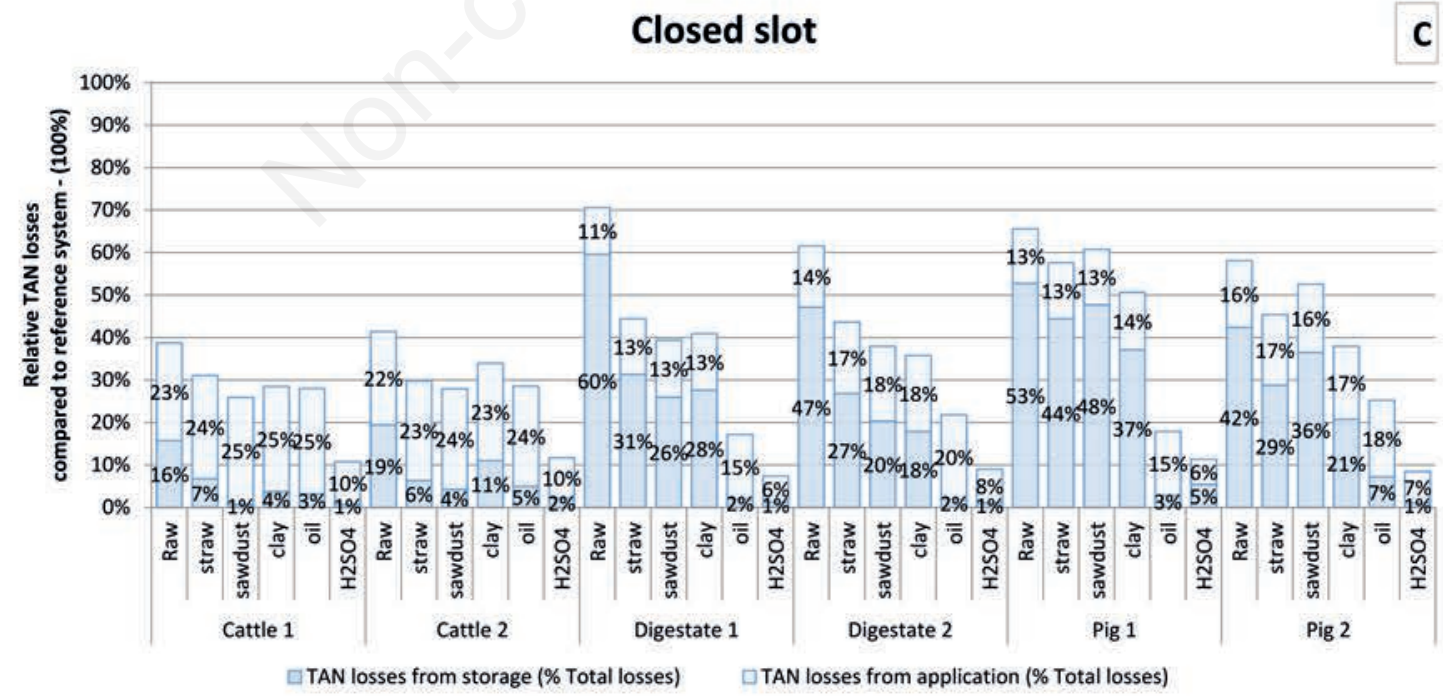

Figure 2. Cumulative losses of total ammoniacal nitrogen (TAN) from the slurry management chain (storage and field application) compared to those from the reference system (storage of raw slurry without mitigation and subsequent broadcast spreading): A) effect of mitigation techniques and their effect on field application using broadcast spreading; B) effects of mitigation techniques coupled with band spreading; C) effects of mitigation techniques coupled with closed-slot injection. 


\section{References}

APHA/AWWA/WEF, 2012. Standard methods for the examination of water and wastewater. Stand. Methods 541.

Balsari P., Dinuccio E., Gioelli F. 2006. A low cost solution for ammonia emission abatement from slurry storage. Int. Congr. Ser. 1293:323-6.

Dinuccio E., Berg W., Balsari P. 2008. Gaseous emissions from the storage of untreated slurries and the fractions obtained after mechanical separation. Atmos. Environ. 42:2448-59.

European Environment Agency. 2017. European Union emission inventory report 1990-2015 under the UNECE Convention on Long-range Transboundary Air Pollution (LRTAP). Available from: https://publications.europa.eu/en/publication-detail//publication/d99f25f2-92ae-11e7-b92d-01aa75ed71a1/language-en

Fangueiro D., Hjorth M., Gioelli F. 2015. Acidification of animal slurry - a review. J. Environ. Manage. 149:46-56.

Feilberg A., Sommer S.G. 2013. Ammonia and malodorous gases: sources and abatement technologies. In: S.G. Sommer, M.L. Christensen, T. Schmidt, L.S. Jensen (Ed.) Animal manure recycling: treatment and management. John Wiley \& Sons Ltd, New York, NY, USA, pp 153-175.

Guarino C., Brambilla M., Valli L., Navarotto P.M.F. 2006. Evaluation of simplified covering systems to reduce gaseous emissions from livestock manure storage. Am. Soc. Agric. Biol. Eng. 49:737-47.

Hafner S.D., Pacholski A., Bittman S., Burchill W., Bussink W., Chantigny M., Carozzi M., Génermont S., Häni C., Hansen M.N., Huijsmans J., Hunt D., Kupper T., Lanigan G., Loubet B., Misselbrook T.H., Meisinger J.J., Neftel A., Nyord T., Pedersen S.V., Sintermann J., Thompson R.B., Vermeulen B., Vestergaard A.V., Voylokov P., Williams J.R., Sommer S.G. 2018. The ALFAM2 database on ammonia emission from field-applied manure: description and illustrative analysis. Agric. Forest Meteorol. 258:66-79.

Hansen R.R., Nielsen D.A., Schramm A., Nielsen L.P., Revsbech N.P., Hansen M.N. 2009. Greenhouse gas microbiology in wet and dry straw crust covering pig slurry. J. Environ. Qual. 38:1311-9.

Hörnig G., Türk M., Wanka U. 1999. Slurry covers to reduce ammonia emission and odour nuisance. J. Agric. Eng. Res. 73:151-7.

Hou Y., Velthof G.L., Oenema O. 2015. Mitigation of ammonia, nitrous oxide and methane emissions from manure management chains: A meta-analysis and integrated assessment. Glob. Chang. Biol. 21:1293-12.

Kai P., Pedersen P., Jensen J.E., Hansen M.N., Sommer S.G. 2008. A whole-farm assessment of the efficacy of slurry acidification in reducing ammonia emissions. Eur. J. Agron. 28:148-54.

McCrory D.F., Hobbs P.J. 2001. Additives to reduce ammonia and odor emissions from livestock wastes: a review. J. Environ. Qual. 30:345-55.

Langevin B., Génermont S., Basset-Mens C., Lardon L. 2015. Simulation of field NH3 and N2O emissions from slurry spreading. Agron. Sustain. Dev. 35:347-58.

Loubet B., Genermont S., Ferrara R., Bedos C., Decuq C., Personne E., Fanucci O., Durand B., Rana G., Cellier P. 2010. An inverse model to estimate ammonia emissions from fields. Eur. J. Soil Sci. 61:793-805.

Misselbrook T.H., Brookman S.K.E., Smith K.A., Cumby T.,
Williams A.G., McCrory D.F. 2005. Crusting of stored dairy slurry to abate ammonia emissions: pilot-scale studies. J. Environ. Qual. 34:411-9.

Misselbrook T.H., Hunt J., Perazzolo F., Provolo G. 2016. Greenhouse gas and ammonia emissions from slurry storage: Impacts of temperature and potential mitigation through covering (pig Slurry) or acidification (cattle Slurry). J. Environ. Qual. 45:1520-30.

Mohankumar Sajeev E.P., Winiwarter W., Amon B. 2018. Greenhouse gas and ammonia emissions from different stages of liquid manure management chains: abatement options and emission interactions. J. Environ. Qual. 47:30-41.

Ndegwa P.M., Hristov A.N., Arogo J., Sheffield R.E. 2008. A review of ammonia emission mitigation techniques for concentrated animal feeding operations. Biosyst. Eng. 100:453-69.

Oenema O., Oudendag D., Velthof G.L. 2007. Nutrient losses from manure management in the European Union. Livest. Sci. 112:261-72.

Petersen S.O., Andersen A.J., Eriksen J. 2012. Effects of cattle slurry acidification on ammonia and methane evolution during storage. J. Environ. Qual. 41:88-94.

Petersen S.O., Højberg O., Poulsen M., Schwab C., Eriksen J. 2014. Methanogenic community changes, and emissions of methane and other gases, during storage of acidified and untreated pig slurry. J. Appl. Microbiol. 117:160-72.

Petersen S.O., Sommer S.G. 2011. Ammonia and nitrous oxide interactions: roles of manure organic matter management. Anim. Feed Sci. Technol. 166-167:503-13.

Portejoie S., Martinez J., Guiziou F., Coste C.M. 2003. Effect of covering pig slurry stores on the ammonia emission processes. Bioresour. Technol. 87:199-207.

Provolo G., Finzi A., Perazzolo F., Mattachini G., Riva E. 2016. Effect of a biological additive on nitrogen losses from pig slurry during storage. J. Environ. Qual. 45:1460-5.

Regueiro I., Coutinho J., Fangueiro D. 2016. Alternatives to sulfuric acid for slurry acidification: impact on slurry composition and ammonia emissions during storage. J. Clean. Prod. 131:296-307.

Rodhe L.K.K., Ascue J., Willén A., Persson B.V., Nordberg Å. 2015. Greenhouse gas emissions from storage and field application of anaerobically digested and non-digested cattle slurry. Agric. Ecosyst. Environ. 199:358-68.

Santonja G.G., Georgitzikis K., Bianca Maria Scalet B.M., Montobbio P., Roudier S., Delgado Sancho L. 2017. Best available techniques (BAT) reference document for the intensive rearing of poultry or pigs. EUR 28674 EN. Publications Office of the European Union, Luxemburg.

Søgaard H.T., Sommer S.G., Hutchings N.J., Huijsmans J.F.M., Bussink D.W., Nicholson F. 2002. Ammonia volatilisation from field-applied animal slurry-the ALFAM model. Atmos. Environ. 36:3309-19.

Thorman R.E., Hansen M.N., Misselbrook T.H., Sommer S.G. 2008. Algorithm for estimating the crop height effect on ammonia emission from slurry applied to cereal fields and grassland. Agron. Sustain. Dev. 28:373-8.

VanderZaag A.C., Gordon R.J., Glas V., Jamieson R.C. 2008. Floating covers to reduce gas emissions from liquid manure storages: a review. Appl. Eng. Agric. 24:657-71.

Webb J., Menzi H., Pain B.F., Misselbrook T.H., Dämmgen U., Hendriks H., Döhler H. 2005. Managing ammonia emissions from livestock production in Europe. Environ. Pollut. 